\title{
Nilai Total Digestible Nutrient pada Bahan Pakan By-Product Industri Pertanian sebagai Pakan Kambing yang Diuji secara In Vitro
}

\author{
Total Digestible Nutrient of Agricultural Industry by-Product Feed Ingridient as Goat Feed \\ with In Vitro Method
}

\author{
A.I. Syafrudin, E. Pangestu dan M. Christiyanto
}

Fakultas Peternakan dan Pertanian, Universitas Diponegoro

Jl. Prof. Soedarto, SH Tembalang 50275, Semarang, Jawa Tengah Indonesia

Corresponding email : adzza15@gmail.com

\begin{abstract}
This research was aimed to evaluate of total digestible nutrient of agricultural industry by- product feed ingredient as goat feed with in vitro method. Rumen fluids came from fistulated Etawah crossbred goat. A completely randomized design with 7 treatments and 3 replications. Palm kernel meal (T1), coffee husk (T2), corn cob (T3), soybean curd waste (T4), soybean meal (T5), coconut meal (T6) and cassava waste (T7). The parameters observed were dry matter digestability, organic matter digestabilty and total digestible nutrient. Data were analyzed using ANOVA and continued with Duncan test. The data result showed that agricultural industry by- product feed ingridient were significant $(\mathrm{P}<0,05)$ on dry matter digestability, organic matter digestability and total digestible nutrient value. In conclusion, coffee husk and palm kernel meal resulted the lowest $(<50 \%)$ dry matter digestability, organic matter digestability, and total digestible nutrient value. Cassava waste, coconut meal, soybean meal, soybean curd waste and corn cob had a high dry matter digestability, organic digestability and total digestible nutrient value.
\end{abstract}

Key words : in vitro, by- product agriculture industries, digestability

\begin{abstract}
ABSTRAK
Penelitian ini bertujuan untuk mengkaji nilai TDN pada berbagai macam bahan pakan by-product industri pertanian yang dilakukan dengan teknik in vitro. Percobaan dilakukan menggunakan cairan rumen yang diambil dari kambing PE berfistula. Percobaan ini menggunakan Rancangan Acak Lengkap yang terdiri atas 7 Perlakuan dan 3 ulangan. Perlakuan tersebut terdiri dari T1 = Bungkil sawit, T2 = Kulit kopi, T3 = Janggel jagung, T4 = Ampas tahu, T5 $=$ Bungkil kedelai, $\mathrm{T} 6=$ Bungkil kelapa dan $\mathrm{T} 7=$ Onggok. Parameter yang diukur pada penelitian ini yaitu kecernaan bahan kering, kecernaan bahan organik dan nilai TDN. Data yang diperoleh dianalisis dengan ANOVA dan dilajut dengan uji jarak berganda Duncan. Hasil analisis menunjukkan bahwa bahan pakan by- product industri pertanian berpengaruh nyata $(\mathrm{P}<0,05)$ terhadap nilai kecernaan bahan kering, kecernaan bahan organik dan nilai TDN. Simpulan dari penelitian ini bahwa bahan pakan kulit kopi dan bungkil sawit memiliki kecernaan bahan kering, kecernaan bahan organik dan nilai TDN yang rendah $(<50 \%)$. Onggok, bungkil kelapa, bungkil kedelai, ampas tahu dan janggel jagung memiliki kecernaan bahan kering, kecernaan bahan organik dan nilai TDN yang tinggi.
\end{abstract}

Kata kunci : In vitro, by- product industri pertanian, nilai kecernaan

\section{PENDAHULUAN}

Pakan merupakan faktor utama yang menunjang produksi ternak terutama ruminansia. Oleh karena itu pakan yang tersedia harus diperhatikan dari segi kualitas, kuantitas dan kontinuitasnya. Upaya yang dilakukan untuk penyediaan bahan pakan yaitu mencari bahan pakan alternatif yang memiliki potensi untuk memenuhi kebutuhan ternak, murah dan mudah diperoleh serta tersedia sepanjang tahun (Riski et al., 2016). Pakan alternatif dapat diperoleh dari hasil samping industri pertanian seperti janggel jagung, kulit kopi, ampas tahu, onggok, bungkil kelapa, bungkil sawit dan bungkil kedelai. Bahan pakan tersebut dapat dimanfaatkan sebagai pakan ruminansia karena berpotensi sebagai sumber energi dan protein. Salah satu alternatif pemecahan masalah tentang ketersediaan bahan pakan untuk ternak ruminansia dengan memanfaatkan bahan pakan yang berasal dari hasil samping industri pertanian (Purbowati et al., 2007).

Hasil samping industri pertanian atau byproduct biasa diartikan sebagai hasil ikutan produk utama atau sisa dari produk utama 
kegiatan pertanian dimana masih terkandung nutrien yang masih bisa dimanfaatkan (Murni et al., 2008). Hasil samping dari industri pertanian di Indonesia tersedia cukup melimpah sehingga dapat digunakan sebagai pakan alternatif pengganti hijauan dalam memenuhi kebutuhan nutrien ternak.

Penggunaan pakan by- product di peternakan rakyat khususnya peternakan kambing tidak disesuaikan dengan kebutuhan. Hal ini menyebabkan ketidakseimbangan pemenuhan nutrien pada ternak. Oleh karena itu, perlu adanya perhitungan dan potensi nilai nutrisi dari bahan pakan tersebut. Kecukupan nilai nutrien dapat dipenuhi salah satunya berdasarkan dari nilai TDN (Total Digestible Nutrients). Nilai TDN menggambarkan jumlah energi yang terserap dalam tubuh yang mempengaruhi produktivitas ruminansia (Supratman et al., 2016). Perhitungan nilai TDN penting dilakukan untuk memenuhi kebutuhan nutrien ternak sehingga produktivitasnya dapat optimal. Penelitian ini bertujuan untuk mengkaji nilai TDN pada bahan pakan by- product industri pertanian.

\section{MATERI DAN METODE}

Penelitian ini dilaksanakan selama 4 bulan di Laboratorium Ilmu Nutrisi dan Pakan, Fakultas Peternakan dan Pertanian Universitas Diponegoro, Semarang. Analisis kecernaan dilakukan di Laboratorium Ilmu Nutrisi dan Pakan, Fakultas Peternakan dan Pertanian Universitas Diponegoro, Semarang.

Materi yang digunakan adalah bahan pakan meliputi janggel jagung, onggok, ampas tahu, kulit kopi, bungkil kelapa, bungkil sawit dan bungkil kedelai yang diperoleh dari peternakan rakyat di Ungaran dan Boyolali.
Cairan rumen yang digunakan adalah cairan rumen kambing yang berasal dari kambing PE berfistula di Fakultas Peternakan dan Pertanian Universitas Diponegoro. Alat yang digunakan dalam analisis in vitro yaitu tabung fermentor dengan tutup karet berventilasi, gelas ukur 100 $\mathrm{ml}$, gelas beker $100 \mathrm{ml}$, labu alas bulat, tabung destilasi, timbangan analitis kapasitas $120 \mathrm{~g}$ dengan ketelitian $0,0001 \mathrm{~g}$, thermometer $100^{\circ} \mathrm{C}$ skala $1^{\circ} \mathrm{C}$, waterbath berisi air hangat dengan suhu $39-40{ }^{\mathrm{O}} \mathrm{C}$, sentrifuse, crusible porselen, kertas saring Whatman no 41, kertas saring lemak, oven, eksikator, pompa vakum dan tanur listrik. Bahan yang digunakan dalam penelitian adalah larutan McDougall, cairan rumen, larutan pepsin $\mathrm{HCL} 0,2 \%$, N-Hexan, larutan $\mathrm{HgCl}$ jenuh. Komposisi ransum dan kadar nutrien bahan pakan disajikan dalam Tabel 1 dan Tabel 2 . berdasarkan hasil analisis di Laboratorium Ilmu Nutrisi dan Pakan, Fakultas Peternakan dan Pertanian Universitas Diponegoro Semarang.

Penelitian dilakukan dalam 4 tahap yaitu, rancangan percobaan tahap persiapan, tahap analisis in vitro dan analisis data.

\section{Rancangan Percobaan}

Rancangan penelitian yang digunakan dalam penelitian ini adalah rancangan acak lengkap (RAL) yang terdiri dari 7 perlakuan dengan 3 ulangan. Perlakuan yang diuji terdiri dari bahan pakan hasil samping industri pertanian meliputi.

TI = Bungkil Sawit

$\mathrm{T} 2=$ Kulit Kopi

T3 = Janggel Jagung

T4 = Ampas Tahu

T5 = Bungkil Kedelai

T6 = Bungkil Kelapa

$\mathrm{T} 7=$ Onggok

Tabel 1. Komposisi Nutrien Ransum Untuk Kambing Sumber Inokulan

\begin{tabular}{lccccccc}
\hline \multirow{2}{*}{ Bahan Pakan } & \multirow{2}{*}{ Komposisi } & \multicolumn{6}{c}{ Kandungan nutrien ransum } \\
\cline { 3 - 7 } & & Abu & PK & LK & SK & TDN & NDF \\
\hline \multirow{3}{*}{ Rumput gajah } & 50 & 6,44 & $-4,64$ & 1,60 & 14,65 & 29,13 & 33,17 \\
Pollard & 10 & 0,39 & 1,57 & 0,43 & 0,45 & 7,65 & 6,93 \\
Onggok & 12 & 1,77 & 1,41 & 0,04 & 1,32 & 8,65 & 5,10 \\
Bekatul & 13 & 1,94 & 0,31 & 1,85 & 1,09 & 5,34 & 4,89 \\
\hline Bungkil kedelai & 7 & 0,51 & 2,85 & 0,13 & 0,13 & 5,48 & 1,25 \\
Bungkil sawit & 8 & 1,13 & 1,46 & 0,78 & 0,74 & 6,06 & 2,87 \\
Total & 100 & 12,19 & 12,23 & 4,82 & 18,38 & 62,32 & 54,22 \\
\hline
\end{tabular}


Tabel 2. Hasil Analisis Proksimat Bahan Pakan Hasil Samping Industri Pertanian

\begin{tabular}{lccccccc}
\hline \multirow{2}{*}{$\begin{array}{c}\text { Kadar } \\
\text { Nutrien }\end{array}$} & \multicolumn{7}{c}{ Bahan Pakan } \\
\cline { 2 - 7 } & K.Kopi & B. Sawit & J.Jagung & A.Tahu & B. Kedelai & B. Kelapa & Onggok \\
\hline Air & 76,5 & 88,7 & 101,7 & 892,7 & 105,3 & 145,8 & 114,4 \\
BO & 966,4 & 966,4 & 956,4 & 956,6 & 967,0 & 963,1 & 958,6 \\
PK & 102,8 & 154,6 & 69,6 & 158,1 & 381,7 & 205 & 59,2 \\
LK & 31,9 & 42,1 & 47,7 & 36,0 & 15,4 & 22,1 & 2,6 \\
SK & 508,9 & 487,7 & 136,6 & 351,5 & 391,0 & 188,0 & 428,5 \\
BETN* & 322,8 & 282 & 702,7 & 411 & 178,9 & 548 & 468,3 \\
NDF & 671,1 & 626,1 & 536,2 & 222,4 & 350,9 & 529,6 & 407,1 \\
ADF & 352,1 & 349,6 & 322,0 & 163,7 & 138,2 & 298,7 & 239,3 \\
NFC & 160,6 & 143,6 & 302,9 & 540,1 & 219,0 & 206,4 & 489,7 \\
Selulosa & 190,8 & 189,3 & 226,1 & 84,1 & 88,3 & 48,6 & 128,2 \\
Lignin & 144,2 & 114,3 & 101,3 & 21,1 & 25,8 & 224,2 & 92,9 \\
\hline
\end{tabular}

Hasil analisis Laboratorium Ilmu Nutrisi dan Pakan, Fakultas Peternakan dan Pertanian Universitas Diponegoro

$* \mathrm{BETN}=100 \%-(\mathrm{Abu}+\mathrm{LK}+\mathrm{SK}+\mathrm{PK})$

\section{Tahap Persiapan}

Tahap persiapan meliputi pengadaan bahan pakan by- product meliputi (kulit kopi yang berasal dari mojosongo, ampas tahu berasal dari produksi olahan kedelai di Ungaran, janggel jagung, bungkil sawit, bungkil kelapa, bungkil kedelai dan onggok berasal dari ungaran). Preparasi sampel dengan cara bahan pakan digiling menjadi tepung, dan analisis proksimat bahan pakan.

\section{Tahap Analisis In Vitro}

Metode pencernaan dibagi menjadi 2 tahap yaitu pencernaan secara fermentatif dan enzimatis. Pencernaan fermentatif dilakukan dengan sampel ditimbang sebanyak 0,55 - 0,56g bahan pakan yang akan diuji ke dalam tabung fermentor, ditambahkan $40 \mathrm{ml}$ larutan McDougall dan $10 \mathrm{ml}$ cairan rumen dan gas $\mathrm{CO}_{2}$, tutup rapat dengan tutup karet berventilasi, sampel dimasukkan ke dalam waterbath yang sudah diisi dengan air bersuhu $39-40^{\circ} \mathrm{C}$. Inkubasi dilakukan selama 48 jam dengan penggojokkan setiap 6 jam sekali setelah inkubasi selesai tutup karet dibuka dan dimasukkan ke dalam sentrifus selama 10 menit untuk memisahkan cairan dan substrat lalu setelah terpisah cairan dibuang.

Cairan yang sudah terpisah dengan endapan ditambahkan dengan larutan pepsin $\mathrm{HCl}$ $0,2 \%$ sebanyak $50 \mathrm{ml}$. selanjutnya dilakukan inkubasi kembali selama 48 jam dengan penggojokan setiap 6 jam sekali. Setelah selesai inkubasi sampel disaring menggunakan kertas saring dengan bantuan pompa vakum. setelah sampel disaring lalu dimasukkanke dalam oven bersuhu $105{ }^{\circ} \mathrm{C}$ selama 12 jam untuk mengetahui bahan kering, dan pengabuan dalam tanur listrik pada suhu $600{ }^{\circ} \mathrm{C}$ selama 6 jam untuk mengetahui bahan organik.

Pengukuran kecernaan lemak dengan menyaring residu pada kertas saring dan dioven selama 6 jam, dimasukkan kedalam soxhlet. Setelah selesai sampel dikeringkan dan dimasukkan kedalam oven selama dan ditimbang berat setelah oven.

\section{Perhitungan KcBK dan KcBO dapat dihitung dengan rumus}

$\operatorname{KcBK}(\%)=\frac{\mathrm{BKs}-(\mathrm{BK} \text { residu }-\mathrm{BK} \text { blanko })}{\mathrm{BKs}} \times 100 \%$

Keterangan:

BKs (BK sampel) $=$ Bobot BK sampel $\mathrm{x} \% \mathrm{BK}$

$\mathrm{KcBO}(\%)=\frac{\mathrm{BOs}-(\mathrm{BO} \text { residu }-\mathrm{BO} \text { blanko })}{\mathrm{BOs}} \times 100 \%$

Keterangan:

BOs $($ BO sampel $)=$ Bobot BO Sampel $\mathrm{x} \% \mathrm{BO}$

$\operatorname{KcLK}(\%)=\frac{\text { LKs-(LK residu-LK blanko })}{\text { LKs }} \times 100 \%$

Keterangan:

LKs $($ LK sampel $)=$ Bobot LK sampel $x \%$ LK

Pengukuran TDN menurut Tillman et al.

(1998) dapat diperoleh dengan: 
TDN (\%)=BOdd (\%)+(LKdd \% x 1,25)

Bodd (\%) : KcBO x BO Pakan

LKdd (\%) : KcLK x LK Pakan

\section{Analisis Data}

Data kecernaan bahan kering, bahan organik dan TDN yang diperoleh pada penelitian dianalisis dengan analisis ragam menggunakan rancangan acak lengkap (RAL). Adanya perbedaan antar perlakuan maka dilakukan uji lanjut Duncan (Srigandono, 1987).

\section{HASIL DAN PEMBAHASAN}

Rataan kecernaan bahan kering, kecernaan bahan organik, kecernaan lemak dan nilai TDN bahan pakan by-- product industri pertanian disajikan dalam Tabel 3.

\section{Kecernaan Bahan Kering (KcBK) Bahan Pakan by-- Product Industri Pertanian}

Berdasarkan Tabel 3. diketahui bahwa hasil analisis ragam $\mathrm{KcBK}$ menunjukkan perbedaan yang nyata $(\mathrm{P}<0,05)$ antarbahan pakan. Kecernaan bahan kering secara berturut dari tertinggi ke terendah yaitu onggok (T7), bungkil kelapa (T6), janggel jagung (T3), ampas tahu (T4), bungkil kedelai (T5), bungkil sawit (T1), dan kulit kopi (T2). Berdasarkan uji Duncan diketahui bahwa nilai kecernaan bahan kering pada bahan pakan kulit kopi dan bungkil sawit berbeda nyata dengan bahan pakan lainnya $(\mathrm{P}<0,05)$. Bungkil kelapa, ampas tahu, bungkil kedelai, onggok dan janggel jagung tidak menunjukkan perbedaan $\mathrm{KcBK}$.

Nilai kecernaan bahan kering yang terendah yaitu kulit kopi dan bungkil sawit hal ini disebabkan oleh kandungan serat NDF pada bahan pakan yang tergolong tinggi dibanding dengan bahan pakan yang lain $671,1 \mathrm{~g} / \mathrm{kg}$ BK dan
$626,1 \mathrm{~g} / \mathrm{kgBK}$. Usman et al. (2013) menyatakan bahwa NDF (neutral detergen fiber) merupakan dinding sel tanaman yang mengandung selulosa, hemiselulosa dan lignin yang merupakan pembatas kecernaan. Kandungan NDF berkorelasi negatif dengan laju pemecahannya. Kandungan NDF yang tinggi akan sulit untuk didegradasi oleh mikroba rumen karena semakin tinggi kandungan serat kasar pada bahan pakan maka kemampuan mikroba untuk memecah pakan di dalam rumen akan semakin lama.

\section{Kecernaan Bahan Organik (KcBO) Bahan Pakan By-Product Industri Pertanian}

Hasil analisis ragam menunjukkan bahwa rataan kecernaan bahan organik menunjukkan perbedaan yang nyata $(\mathrm{P}<0,05)$ antar bahan pakan by-product industri pertanian. Uji Duncan menunjukkan kecernaan bahan organik pada bahan pakan kulit kopi dan bungkil sawit berbeda nyata dengan bahan pakan lainnya $(\mathrm{P}<0,05)$. Bungkil kepala, ampas tahu, bungkil kedelai, onggok dan janggel jagung tidak menunjukkan perbedaan KcBO.

Bedasarkan tabel 3, dapat diketahui bahwa rataan kecernaan bahan organik $(\mathrm{KcBO})$ pada masing-masing perlakuan adalah $\mathrm{T} 1$ (49.53), T2 (22.11), T3 (66.69), T4 (67.77), T5 (67.18), T6 (71.85), T7 (74.1). Kulit kopi dan bungkil sawit memiliki kecernaan bahan organik terendah dibandingkan bahan pakan lainnya, hal ini disebabkan karena memiliki kandungan lignin yang tinggi. Anindyawati (2010) Lignin merupakan fraksi ADF yang sulit dicerna oleh mikroba rumen sehingga berpengaruh negatif terhadap kecernaan nutrien bahan pakan, struktur lignin berikatan dengan selulosa sehingga sulit dipecah. Kandungan lignin yang rendah akan memudahkan mikroba rumen untuk mencerna pakan secara optimal, sebaliknya apabila kandungan lignin dalam pakan tinggi maka

Tabel 3. Rataan kecernaan bahan kering, kecernaan bahan organik, kecernaan lemak dan nilai TDN

\begin{tabular}{lcccc}
\hline \multirow{2}{*}{ Bahan Pakan } & KcBK & KcBO & KcLK & TDN \\
\cline { 2 - 5 } & $(\%)$ & $(\%)$ & $(\%)$ & $(\%)$ \\
\hline Kulit kopi & $40.86^{\mathrm{b}}$ & $49.53^{\mathrm{b}}$ & $98.25^{\mathrm{a}}$ & $42,90^{\mathrm{b}}$ \\
Bungkil sawit & $21.41^{\mathrm{c}}$ & $22.11^{\mathrm{c}}$ & $94.95^{\mathrm{b}}$ & $26.77^{\mathrm{c}}$ \\
Janggel jagung & $64.23^{\mathrm{a}}$ & $66.69^{\mathrm{a}}$ & $98.97^{\mathrm{a}}$ & $69.86^{\mathrm{a}}$ \\
Ampas tahu & $63.11^{\mathrm{a}}$ & $67.77^{\mathrm{a}}$ & $97.57^{\mathrm{a}}$ & $70.88^{\mathrm{a}}$ \\
Bungkil kedelai & $61.98^{\mathrm{a}}$ & $67.18^{\mathrm{a}}$ & $97.57^{\mathrm{a}}$ & $70.27^{\mathrm{a}}$ \\
Bungkil kelapa & $67.37^{\mathrm{a}}$ & $71.85^{\mathrm{a}}$ & $98.06^{\mathrm{a}}$ & $74.79^{\mathrm{a}}$ \\
Onggok & $67.78^{\mathrm{a}}$ & $74.1^{\mathrm{a}}$ & $78.83^{\mathrm{c}}$ & $76.32^{\mathrm{a}}$ \\
\hline
\end{tabular}

Superskrip berbeda pada kolom yang sama menunjukkan perbedaan nyata $(\mathrm{p} \leq 0.05)$. 
mikroba dalam rumen akan sulit untuk mencerna pakan sehingga nilai kecernaan yang diperoleh tidak optimal. Tillman et al. (1998) menyatakan bahwa kandungan lignin dalam pakan menyebabkan nilai fermentasi dan degredasi pakan rendah karena serat kasar berupa selulosa serta hemiselulosa yang saling berikatan sehinggga sulit dipecah oleh enzim pencernaan.

Salah satu faktor yang dapat menyebabkan nilai kecernaan bahan organik pada kulit kopi rendah adalah faktor pembatas anti nutrien pada bahan pakan. Badarina et al. (2014) menyatakan bahwa kulit kopi memiliki zat anti nutrien berupa kafein, tannin dan polifenol. Zat anti-nutrien tannin pada kulit kopi mampu mengganggu aktivitas kecernaan. Min et al. (2000) menyatakan bahwa zat anti-nutrien tannin dapat menurunkan kemampuan degradasi mikroba rumen dan pelarut protein sehingga berpengaruh negatif pada kecernaan

\section{Nilai Total Digestible Nutrient (TDN)}

Nilai total digestible nutrient berasal dari kecernaan nutrient pakan mulai dari komponen protein, karbohidrat dan lemak dapat dicerna (Van Soest, 1994). Hasil analisis ragam (Lampiran 6) menunjukkan bahwa terdapat perbedaan nilai TDN yang nyata $(\mathrm{P}<0,05)$ antar berbagai macam bahan pakan by- produt. Nilai TDN yang paling tertinggi dan ke terendah yaitu onggok (T7), bungkil kelapa (T6), ampas tahu (T4), bungkil kedelai (T5), janggel jagung (T3), bungkil sawit (T1) dan kulit kopi (T2) ditampilkan dalam Tabel 3.

Berdasarkan uji beda wilayah Duncan dapat diketahui bahwa nilai total digestible nutrient kulit kopi dan bungkil sawit lebih rendah $(\mathrm{P}<0,05)$ terhadap janggel jagung, ampas tahu, bungkil kedelai, bungkil kelapa dan onggok. Bungkil sawit dan kulit kopi memiliki nilai TDN yang terendah, hal ini disebabkan oleh rendahnya kecernaan bahan organik pada bungkil sawit dan kulit kopi (Tabel 3). Kecernaan bahan orgnaik sangat mempengaruhi nilai TDN karena sebagian besar nutrien bahan pakan terkandung dalam bahan organik. Saputro et al. (2016) nilai TDN berhubungan erat dengan bahan organik yang merupakan gambaran ketersediaan nutrien dalam pakan yang dapat dicerna.

Tingginya kecernaan bahan organik menyebabkan nilai TDN juga tinggi. Hambadoku dan Ina (2019) menyatakan bahwa kecernaan bahan kering dan bahan organik yang tinggi akan menghasilkan nilai TDN yang tinggi dan begitu pula sebaliknya. Hal ini disebabkan karena bahan organik menghasilkan energi yang dimanfaatkan untuk pertumbuhan mikroba di dalam rumen. Energi digunakan oleh mikroba untuk melakukan aktvitasnya, sehingga semakin tinggi nilai kecernaan bahan organik maka semakin banyak kandungan nutrien pakan yang mampu dicerna.

\section{KESIMPULAN}

Berdasarkan hasil penelitian dapat disimpulkan bahwa bahan pakan kulit kopi dan bungkil sawit memiliki kecernaan bahan kering, kecernaan bahan organik dan nilai TDN yang rendah $(<50 \%)$. Onggok, bungkil kelapa, bungkil kedelai, ampas tahu dan janggel jagung memiliki kecernaan bahan kering, kecernaan bahan organik dan nilai TDN yang tinggi.

\section{DAFTAR PUSTAKA}

Anindyawati, T. 2010. Potensi selulase dalam mendegradasi lignoselulosa limbah pertanian untuk pupuk organik. Berita selulosa. 45 (2): 70 - 77.

Badarina, I., D. Evvyernie, T. Toharmat, E. N. Herliyana. 2014. Fermentabilitas rumen dan kecernaan in vitro ransum yang disuplementasi kulit buah kopi produk fermentasi jamur Pleurotus ostreatus. Jurnal Sain Peternakan Indonesia 9 (2): $103-109$.

Hambadoku, M dan Y.T.Ina. 2019. Evaluasi kecernaan In Vitro bahan pakan hasil samping agro industri. Jurnal Agripet. 19 (1): 7 - 12 .

Min, B.R., W.C. Mcnabb, T.N. Barry and J.S. Peters. 2000. Solubilization and degradation of ribulose-1,5bisphosphate carboxylase/oxygenase (EC 4.1.1.39; Rubisco) protein from white clover (Trifolium repens) and Lotus corniculatus by- rumen microorganisms and the effect of condensed tannins on these processes. J. Agric. Sci. (Camb.) 134: 305-317.

Murni, R, Suparjo, Akmal, dan B.L.Ginting. 2008. Buku Ajar Teknologi Pemanfaatan Limbah untuk Pakan. Laboratorium Makanan Ternak. Fakultas Peternakan universitas Jambi. 
Purbowati, E., C.I. Sutrisno, E. Baliarti, S.P.S. Budhi dan W. Lestariana. 2007. Pengaruh Pakan Komplit dengan Kadar Protein dan Energi yang Berbeda pada Penggemukan Domba Lokal Jantan secara feedlot terhadap Konversi Pakan. Prosiding Seminar Nasional Teknologi

Riski, P., B. P. Purwanto dan A. Atabany. 2016. Produksi dan kualitas susu sapi FH laktasi yang diberi pakan daun pelepah sawit. Jurnal ilmu Produksi dan Teknologi Hasil Peternakan. 4 (3): 345 349.

Saputro, T. S. D. Widyawati dan Suharto. 2016. Evaluasi nutrisi perbedaan rasio dedak padi dan ampas bir ditinjau dari nilai TDN ransum domba lokal jantan. Jurnal Sains Peternakan. 14 (1): 27 - 35.

Supratman, H., Setiyatwan, H., Budinuryanto, D.C., Fitriani, A., Ramdani, D., 2016. Pengaruh imbangan hijauan dan konsentrat pakan komplit terhadap konsumsi, pertambahan bobot badan dan konversi pakan domba. Jurnal Ilmu Ternak. 16 (1): 31 - 35

Tillman, A. D., H. Hartadi, S., S. Reksohadiprodjo., S. Prawirokusomo dan S. Lebdosoekojo. 1998. Ilmu Makanan Ternak Dasar. Gadjah Mada University Press, Yogyakarta.

Usman,Y., M. N Husin dan R Ratni. 2013. Pemberian kulit biji kopi dalam ransum sapi aceh terhadap kecernaan secara In Vitro. Puslitbang Peternakan, Bogor. 13 (1) :49-52.

Van Soest, P. J. 1994. Nutritional Ecology Of The Ruminant. 2nd Ed., Comstock Publishing Associates, Cornell University Press, London. pp: 177-195. 